\title{
The Needs of People in Tambak Lorok Semarang towards Knowledge
}

\author{
Rizki Nurislaminingsih, Edwin Rizal \\ Department Communication and Information, Faculty of Communication Science, \\ Universitas Padjadjaran, Indonesia
}

DOI: https:// 10.14710/jmsni.v3i2.6130

\begin{abstract}
This research has an argumentation that people in Tambak Lorok need additional knowledge to facilitate their work as fishermen. This need is also based on the need to find solutions to problems they often face, such as poverty and lack of it due to dropping out of school. A qualitative approach was used in this study to explore what their necessaries are for knowledge and the reasons behind it. The researchers then use a narrative strategy to describe the research findings. The results show that people in Tambak Lorok need knowledge about marine affairs, technology to catch fish, skills about

Received:

October 20, 2019

Accepted:

December 8, 2019

*Corresponding Author:

nurislaminingsih@unpad.ac.id processing marine products, marketing techniques and about the history of their area or their identity as sailors. They need teachers who are willing to provide training as often as possible with a variety of science themes. They also need additional educational facilities such as village libraries and volunteer teachers as a source of independent learning, especially for children.
\end{abstract}

Keywords: Fishermen; Knowledge Needs; Village Library.

\section{Introduction}

This research is a continuation of our two previous studies which indicate the need of Tambak Lorok community for knowledge. According to Nurislaminingsih (2017, 10043-10044) village library as a source of knowledge for the community, especially for children. Informants also want books on creativity, flood prevention, and waste utilization. This is reinforced by the results of subsequent studies (Nurislaminingsih and Ganggi 2017, 220) which show that actually Tambak Lorok residents really need additional knowledge. This can be seen from the active participation of citizens in the socialization of work safety for fishermen, counseling about hydroponics, training on entrepreneurship and management of mangrove forests that have been held by the government or other volunteers at the floating reading house. Therefore, it can be understood that the Tambak Lorok community hopes various types of science and at the same time requires facilities that connect them with access to it.

Tambak Lorok is a coastal area of Semarang where most of the residents work as fishermen. The work of the fishermen can be directly sold at the Fish Auction Place in the region. Tambak Lorok also has another potential as a place to process sea catches because it has established a simple factory to make Terasi (shrimp paste) and Bandeng Presto (boiled milkfish with seasonings). However, based on the results of Fama's research $(2016,69-72)$ the largest fishing village in Semarang is included in the list of villages that are below the poverty line. Human resources that have not mastered the science and technology of catching fish and post-harvest fish processing technology are one of the causes of the economy of citizens not developing. They need additional knowledge to make new products from the catches of marine animals to increase the income.

In connection with that matter, the results of an interview with Mr. TY when researchers conducted a pre-research visit showed that residents admitted that most fishermen in Tambak Lorok only took elementary school education, even today there are still people dropping out of 
school. He gave an example through himself. As a person who only graduated from elementary school, he claimed to really need new knowledge. As a fisherman, he wants to know about modern fishing techniques or how to process seafood. When asked the reason for this need, he explained that if you could master a better way to catch fish, automatically the catch of marine animals would also increase. If the family has a way to make food creations from fish, shrimp, squid or crabs, the processed products will also have a higher selling value when compared to sales in raw condition.

The statement of the informant was then linked to the availability of educational facilities there. From pre-research observations we know that there is only one formal school, Taqwiyatul Wathon Elementary School. This fact makes the community's access to search for insight feel very limited. The science provided by teachers in elementary schools will not be able to meet the needs for the community, especially those of adulthood. Based on the results of an interview with one of the residents and the reality of the lack of learning facilities, it can be known that the residents of Tambak Lorok need something that can be a representation of the school, so that people, especially adults, can continue to increase their capacities even through independent learning.

Other educational facilities in Tambak Lorok are three public learning places (Public Learning Place). Those simple buildings that have been known by residents as the village library are Rumah Baca Seroja, Rumah Baca Apung and Rumah Pintar Teratai 414. Rumah Baca Seroja and Rumah Pintar Teratai 414 have been temporarily focused on learning activities for children. The Floating Reading House is used by children to learn and is also used by adults as a community meeting hall (a place for socializing, counseling or training). Through these activities, residents learn various knowledge about marine and environmental conditions.

The importance of awareness of it to be mastered by people who live on the coast, especially when dealing with climate change. Climate which suddenly becomes extreme not only affects themselves but also affects the condition of the sea, including mangroves, coral reefs and all the animals that live in the sea. This change will affect their livelihoods. Damage to mangroves and coral reefs will have an impact on the reduction in catches of marine animals. Sooner or later the climate change event will have an impact on reducing the income of citizens. From this event, fishermen are expected to be able to learn to conduct nurseries and rejuvenation of the marine biota ecosystem. This activity is a fishermen's strategy in dealing with uncertain coastal climate change (Mohammed 2017, 200-201).

From that explanation it can be understood that the adults in Tambak Lorok only graduated from elementary school. There is also not yet available public facilities for them to learn independently. When in fact they need skills to support their work. We argue that the people in Tambak Lorok actually need additional knowledge to facilitate their daily activities, especially as fishermen to create processed food products from seafood. Therefore, this study aims to examine more deeply what are the needs of the Tambak Lorok community for knowledge and the reasons underlying it.

\section{Method}

This study aims to determine people's need for knowledge, therefore using a qualitative approach with a narrative strategy. Creswell $(2015,64)$ argues that a qualitative approach is used to explore problems in certain communities and guide researchers to explore the problem in more detail because it is obtained directly from public speaking. Clandinin and Connelly in Creswell $(2016,21)$ assess the narrative strategy as providing opportunities for researchers to investigate the lives of individuals and ask them to tell their lives. The information obtained is then retold by researchers in narrative chronology.

Sources of data in this study in the form of interviews and literature review. According to Creswell $(2016,267)$, data collection on qualitative research can be done by face to face interviews, telephone or focus group discussion. Creswell $(2016,42)$ argues that for qualitative research aimed at exploring participant opinion, literature review is useful for strengthening the introduction, explaining the background of the problem, anyone who has written and researched a similar 
problem. Literature review in this study sourced from books and journals. The validity of the data is done by re-analyzing the results of research with informants (member checking), comparing with existing theories and discussing with fellow researchers (Creswell 2016, 288). The informants in this study consisted of 4 citizens (initials TY, U, I, and Z) and 3 other informants (initials D, S, and M) with volunteer teaching status in public learning places as supporting the validity of the data.

The results of interviews with informants are summarized, then sorted according to their needs for knowledge and their reasons. We ask the informant back to complete the data which is unclear in the description. Then we use the literature from books and journals to look for theories or similar research to strengthen the scientific side of the results of the interview. Finally, we discuss the results of data analysis with fellow researchers who have a common interest in the study, namely the community's need for knowledge. After that we write it in the presentation in the results and discussion.

\section{Results and Discussion}

Referring to the explanation in the introduction, it can be seen that the Tambak Lorok community needs additional knowledge to help solve the problems of daily life. The work of the majority of fishermen also influences the diversity of the needs such as the types of marine animals, the right time to go sailing, how to master trade in the market. and to improve their skills in making new products (processed food from seafood). That requirement is not only for their personal interests, but also to educate their children to become smarter people. A similar expression was conveyed by Spiekermann et al. $(2015,98)$ that the essence of knowledge is the ability to determine decisions and take certain actions. He added that being able to make the best decisions does not only depend on the mastery of that, but must be balanced with experience in dealing with problems. Thus a person will get valuable lessons in his life so he can be careful to determine solutions based on the lessons, experience, and expertise he has.

Based on this analysis we describe the problem through an analysis of the educational necessities of adults with the concept of andragogy belonging to Knowles, Holton, and Swanson in Kroth (2014, 22-23), namely (1). Adults need to know why they need to learn something before learning, (2). The self-concept of adults is heavily dependent upon a move toward self-direction, (3). Prior experiences of the learner provide a rich resource for learning, (4). Adults typically become ready to learn when they experience a need to cope with a life situation or perform a task, (5). Adult orientation to learning is life-centered; education is a process of developing increased competency levels to achieve their full potential, (6). The motivation for adult learners is internal rather than external.

\section{Adults need to know why they need to learn something before learning}

Adults are motivated to learn because they have a passion for learning, just like when they were in school. They are aware of the reasons for learning. This awareness then becomes the starting point for organizing appropriate learning activities for themselves. They are aware of certain learning methods that fit their interests. This is in line with the statement of informant $U$ that Tambak Lorok residents, especially he felt they could not follow the development of science and technology. He further expressed the desire that there is a village library that provides books or newspapers to be read by the public, especially adults.

Tambak Lorok community's need for independent learning facilities is justified by mister D (volunteer at Rumah Pintar Teratai 414). Mister D admitted, before deciding to establish Rumah Pintar Teratai 414, he had conducted a simple survey to explore community needs for lore sources. The survey results show that the community needs a village library, especially those who drop out of school. The community recognizes the demands of the times that encourage them to continue to improve their abilities. Therefore the village library that provides books and volunteer teaching is very much needed. 
The role of a learning place for residents similar to a village library has already been exemplified by Windarsari, Djono and Sunardi $(2017,533)$ through Sanggar Kegiatan Belajar Sukoharjo (Learning Activity Center), which was established by the local government to facilitate communities who want to increase the skill. There is also available reading material in accordance with the needs of participants. Students in these non-formal schools consist of residents who have dropped out of school, housewives and part-time workers. They are 14 to 50 years old. The learning activities they do are not as strict as in formal schools. Teachers at SKB Sukoharjo have special learning techniques that are directed to explore the potential of citizens, such as products or local culture that can be created into something that has economic value. The focus of their learning is to increase creativity, skills, and expertise, not natural or social science as in formal schools.

\section{The self-concept of adults is heavily dependent upon a move toward self-direction}

Adults should get used to learning independently. They can choose where to study and can determine for themselves what they will learn without depending on formal schooling. Therefore, the learning process also needs to be adapted to these conditions. For them, the teacher is not someone who only talks in front of the class. They need teachers as trainers who are willing to be involved in the learning process continuously. The teacher must be a patient person in guiding his students. Based on the explanation, it can be understood that adults really need non-formal education in order to increase proficiency. Specifically, Windarsari $(2017,675)$ mentions nonformal education including life skills education, early childhood education, literacy or equality education. This type of education is carried out flexibly in accordance with the wishes, needs and time of the learners.

The experience of the informant $S$ as a teacher at Rumah Baca Seroja made him thinking about holding potential development activities for mothers who live around Seroja. He further said, so far the mothers only took their children to study at Seroja. While waiting for children to learn, they prefer to talk to each other, not read books or study together. Whereas in Seroja there are also several books that are suitable for adulthood. That means their learning awareness is still limited to increase the science for their children, not for themselves. He believes that the group discussions between the mothers are better replaced by more useful things such as skills training so that they can make money.

Mister S's idea to improve learning among parents has been done by people from other regions. Rohman and Sukaesih's research results $(2017,51)$ prove that through an active learning process in the Margamukti village library, farmers can apply expertise about planting conjoined pumpkin better than when they have not been actively visiting the village library. In addition, the community can also develop the ability to cultivate and organize ornamental plants in a narrow area. These activities increasingly add to the creativity of citizens. Thus citizens are automatically able to increase income.

In line with the phrase mister $S$ which implies the unwillingness of mothers to study at public learning places, informant I (a mother) also said that most Tambak Lorok residents who were mothers were part-time workers in the factory. They are very busy figures. This fact made them feel they did not have much time to actively study in the village library. She said if there is skills training that is not continuing they will definitely want to follow. However, She acknowledged that the residents really needed a village library. For residents who have children, the village library is considered as an extra source of the insight for their children apart from school.

This was reinforced by the statement of the manager of the Rumah Baca Apung, miss M, that there was a time when several parents asked the reason that the public learning place has not held activities for 4 months. They want the village library to keep on doing activities every week so that their children can continue to study at the place. This is because they feel less able to follow the development of insight so it is difficult to teach children, especially school material. They have high hopes that the volunteers of the Rumah Baca Apung are still willing to help their children in learning. From the narrative of Miss M, it can be seen that the Tambak Lorok community really needs volunteers who are willing to guide their children in exploring various sciences. 


\section{Prior experiences of the learner provide a rich resource for learning}

Experience is the richest learning resource for adults. They can take lessons from experience even without guidance from formal teachers. The more mature they are, the better they will think. This is as stated by informant $\mathrm{Z}$ that his ability as a fisherman comes from the learning by doing process that is obtained when going to sea with his father and siblings. When at sea he often faces problems, such as storms, strong winds and heavy rain. At that time his father and brother taught how to save themselves when the problem came. However, mister $\mathrm{Z}$ hopes to someday be able to master more modern technology to catch fish in order to get more results than using simple equipment. The results of the researchers' field visits also provide the same information. We saw for themselves the process of citizens learning to make simple nets and other fishing equipment for fishing. They have not mastered the advanced technology to catch fish and other seafood.

The results of natural self-study have been successfully carried out by fishermen on the California coast. Yochum, Richard, and Dean $(2011,597)$ explained that fishermen in the area have unique qualifications for fishing. They can identify environmental variables that can affect fish distribution and aggregation (for example through seasonal climate change). They realize the behavior of fish will be different in different seasons. The self-taught learning outcomes of fishermen through experience are also explained in the research of Rosa, Adriana and Ronaldo $(2014,261)$ that they are able to realize the diversity of fish species has decreased in the lagoon. The construction of a bridge between Doce River and the lagoon including the culverts underneath hinders fish migration from the estuary into the Extremoz Lagoon. Other fishermen suspect that predators are the main reason for the loss of biodiversity in the lagoon. According to them, 10 years ago the lagoon had around 22 species of fish, now only 13.

In connection with this, Smith in Bear $(2012,29)$ believes learning for adults is a long process that will gradually grow awareness of the importance of learning. Over time, the expertise of adult learners will be honed. He will be able to evaluate the right and wrong of the process he is going through. In the end, he was able to understand that the learning activities were useful or not for himself. This experience makes it able to make decisions, continue or stop learning activities.

The independent learning process for fishermen can also be obtained from daily activities. This is important to do to make it easier for them to look for animals in the sea. Farr, Joshua, and Christine (2018) emphasize the importance of having ecosystem-based local ecological proficiency for the community. For example, fishermen understand that in May and June jellyfish will look for plankton. These activities cause the water to heat up. It impacts on the migration of lobsters to the north. Fishermen's understanding the changing animal behavior makes them easy to catch fish, jellyfish, and lobster. At that time the catch of fishermen will be abundant.

Similar to that statement, Maddox and Rignhild $(2009,35)$ also assume that so far the low level of education is a representation for the fishing community. The formal education that they have taken seems to be of no use to their work. The science they got from school didn't teach them how to become better fishermen. Formal education qualifications do not support their readiness to enter the labor market. Therefore, other efforts are needed so that work as a fisherman can continue to exist along with the times. Fishermen in Bangladesh and Ghana gradually implement independent learning practices to support their livelihoods. Under the guidance of the chief fishermen and community leaders, they learn about marketing, environmental management, technology utilization and so on. This learning experience will later become literacy all the time for fishermen in those two countries.

\section{Adults typically become ready to learn when they experience a need to cope with a life situation or perform a task}

Adults tend to feel ready to learn when they are in a position of being pressured by the reality of life that is being experienced. They will be eager to learn if they really need additional knowledge. They are not used to studying independently on a regular and scheduled basis. For example, when he wants to visit the city of $\mathrm{X}$, then he realizes that before leaving for the place must learn about the 
situation and condition of city X, how the character of the population, the type of food, the weather to the culture.

The important role of knowledge is now beginning to be applied in African coastal communities. It is taken into account in the selection of fishermen heads in an area called Moree. The community wants the people who become the chief fishermen are educated people. Understanding of fisheries, equipment, market share, and business opportunities has become the main requirement to be chosen as the chief fisherman. Educated people are considered capable of being community guides and intermediaries in coastal community-based management activities (Maddox and Rignhild 2009, 43).

An urgent need for additional of it is also experienced by residents of Tambak Lorok. Informant TY said that Tambak Lorok residents really need a library that provides a means to learn to read and write along with volunteer teachers who are willing to guide these activities. This is because until now there are still people who are illiterate (unable to read). These conditions make them feel uncomfortable because they want to be able to read all the writings that have been encountered, such as children's school books, banners or announcement leaflets that are on the street or old newspapers that are wrapped in spices. They also need another science to accompany the children to do the homework given by the teacher.

From that explanation, it can be seen that the learning requirements of adults are based more on finding solutions to the problems that are being experienced. They need a learning process of expertness that can be applied in life. This as stated by Bear $(2012,32)$ orientation of adult learning is leading to problems of life, daily work or problem-solving. In contrast to the learning process of formal school children who are conditioned in a span of study of several years, education for adults is a lifetime education. Lifelong independent learning is what is called literacy.

The importance of literacy for fishermen has been felt by several residents on the coasts of Bangladesh and Ghana. For example, a canoe owner in an area called Moree, he needs literacy to interact with foreign parties who start coming to his area. Business negotiations between local fishermen and foreign guests will not succeed if they do not master the international language and do not understand how to work with world-class. This poor communication proved to have an impact on the failure of the fishermen to establish business networks with foreigners (Maddox and Rignhild 2009, 43-44).

Maddox and Rignhild $(2009,43)$ say a simple form of literacy occurs in the process of buying and selling at the ports of Takoradi and Tema. Women in the region often buy frozen fish from foreign traders. Realizing that their knowledge was limited, the women used to rely on friends or relatives who could help them buy the imported fish. They also often ask everything about fish to truck drivers or mini-bus drivers who transport imported fish. Through colleagues, relatives or truck drivers the women on the coast of Takoradi and Tema do not lack information about the process of buying and selling imported fish. Knowledge acquisition from the process of learning by doing is also a study in the research of Berkström et al. (2019, 4-6) that respondents' knowledge about the environment was gained through direct experience $(63 \%)$, sharing knowledge with fellow fishermen (29\%), fisheries seminars and formal education (8\%). Further explained, most fishermen have high understanding of fish migration from various habitats around the Zanzibar sea, both ontogenetic migration and spawning migration. The fisherman acknowledged that his ability is gained from their experience interacting with many fish species.

\section{Adult orientation to learning is life-centered: Education is a process of developing increased competency levels to achieve their full potential}

Adult learning orientation is about everything related to his life. Education is considered as a process to develop the potential he has to be useful in his daily activities. Therefore, learning facilities and infrastructure for adults need to be focused on learning about life situations, not subjects such as formal education. Based on the explanation of Mrs. I, residents who are parents are more happy if the learning activities for them are packaged in the form of direction by experts, not just reading a book. Their interest in coming to the Seroja is still limited to utilizing the place as a location for 
socialization activities, such as waste management organized by expert volunteers. They did not intend to deliberately come to Seroja just to read a book.

In this regard, community empowerment in Margamukti Village by library practitioners can be an example of the success of programs aimed at improving the welfare of citizens. Literacy-Based Garbage Bank Program that aims to change the public's view of waste into a mainstay activity to stimulate citizens' businesses to increase income. The items that have been deemed useless have been converted into raw materials for various handicrafts, such as making plant polybags from plastic bags of liquid soap or cooking oil. Thus the community can gain knowledge and solutions to increase their income (Rohman and Sukaesih 2017, 51).

\section{The Motivation for Adult Learner is Internal Rather than External}

This study raises interesting findings about the community's need for knowledge. Informant D said that the community needed a history book about their area, namely Tambak Lorok and Semarang. He argues that some residents have been too focused on activities to find work and earn money, so they forget the history of their homes. Thus it can be understood that people do not merely need books about their daily work. Based on this statement it can also be seen that residents who incidentally as coastal residents began to search for information about their identity or origin, especially as fishermen.

The benefits of reading history books have been described in Wasino $(2017,113)$ that Indonesian national figures, such as President Soekarno, Abdul Gani, and Muhammad Yamin, are known to be inspirational figures who like to read history books. History books are a means of interpreting one's position in Indonesian history as the basis of national existence. Besides, Sulistiyono $(2017,56)$ also outlines the assumption of the genealogy of the Indonesian people that can be known from a song that is usually played by children. The history of the existence of a person or group of people in Indonesia cannot be separated from folklore singing in the community that the ancestors of Indonesian people are the sailor.

Not only that, studying history also means that learning about life. The term Historia Magistra Vitae that we have been hearing about suggests that history is a teacher of life. That means, we can learn from events that have passed. From past events, we can be inspired to do something better in the present for the good in the future. The past can also be a source of new knowledge and improve skills to support current activities (Windarsari 2017, 675-676).

\section{Conclusion}

This study concludes that the Tambak Lorok community has diverse knowledge needs based on the search for solutions to life problems that are often experienced, i.e. minimal economic income, poverty, illiteracy and lack of mastery of science. As traditional fishermen, they expect the existence of experts who are willing to teach the use of technology for fishing. They also need it to improve their expertise in making processed foods from marine animals and better ways of selling. As people who drop out of school, they really need facilities to replace formal education to be able to study independently. The study found that adults in Tambak Lorok not only wanted it for themselves, they also needed secondary educational facilities such as village libraries and volunteer teachers as other sources of science for their children. This is based on their awareness of the lack of ability to educate children in the modern times like today. Another finding of this research is the hopes of the residents of the history book about Tambak Lorok and their history as fishermen.

\section{References}

Bear, Anne A. Ghost. 2012. “Technolgy, Learning and Individual Differences.” Journal of Adult Education 41, No 2. https://eric.ed.gov/?id=EJ997574 
Berkström, Charlotte., Myron Papadopoulos, Narriman Saleh Jiddawi, and Lina Mtwana Nordlund. 2019. "Fishers' Local Ecological Knowledge (LEK) on Connectivity and Seascape Management." Frontier in Marine Science 6. doi: 10.3389/fmars.2019.00130

Creswell, J. W. 2015. Penelitian Kualitatif \& Desain Riset: Memilih di antara Lima Pendekatan. Yogyakarta: Pustaka Pelajar.

Creswell, J. W. 2016. Research Design: Pendekatan Kualitatif, Kuantitatif dan Mixed, Yogyakarta: Pustaka Pelajar.

Fama, Achmad. 2016. "Komunitas Masyarakat Pesisir di Tambak Lorok, Semarang." https://ejournal.undip.ac.id/index.php/sabda/article/download/16047/11892

Farr, Emily R., Joshua S. Stoll and Chirstine, M. Beitl. 2018. "Effects of Fisheries Management on Local Ecological Knowleddge.” Ecology and Society 23 (3): 15. https://doi.org/10.5751/ES10344-230315

Kroth, Michael. 2014. "Reflections of Lifelong Learner Teaching in Italia." Journal of Adult Education 43 (2). https://eric.ed.gov/?id=EJ1047366

Maddox, Brian and Rignhild Overa. 2009. "New Technologies, New Demands and New Literacies: The Changing Literacy Practices of Fishing Communities in Bangladesh and Ghana." MAST 8 (2): 35-51. www.marecentre.nl > mast > documents > Mast82_Maddox_Overa

Mohammed, Koya K., Gyanranjan Dash, Sonia Kumari, Sreenath K.R, Makwana N.P, Swatipriyanka Sen Dash, Ambrose T.V., Shyam Salim Shyam, V. Kripa, and Zacharia, P. U. 2017. "Vulnerability of Coastal Fisher Households to Climate Change: A Case Study from Gujarat, India." Turkish Journal of Fisheries and Aquatic Sciences (17): 193-203. DOI: 10.4194/1303-2712-v17_1_21

Nurislaminingsih, Rizki. 2017. "Attitudes of Fishermen in Tambak Lorok Semarang Towards Library.” Advanced Science Letters 23, No 10. https://doi.org/10.1166/asl.2017.10381

Nurislaminingsih, Rizki and Roro Isyawati Permata Ganggi. 2017. "Analisis Pemanfaatan Rumah Baca Apung oleh Masyarakat di Desa Tambak Lorok.” Berkala Ilmu Perpustakaan dan informasi 12, No. 2: 217-226. DOI: 10.22146/bip. 27564

Rohman, Asep Saeful and Sukaesih. 2017. "Transformasi Perpustakaan Desa Untuk Pemberdayaan Masyarakat: Studi Kasus Di Desa Margamukti - Pangalengan Bandung.” Jurnal Perpustakaan Pertanian Vol. 26 No. 2: 47-54. DOI: 10.21082/jpp.v26n2.2017.p47-54

Rosa, Roberto., Adriana R. Carvalho, and Ronaldo Angelini. 2014. "Integrating Fshermen Knowledge and Scientific Analysis to Assess Changes inFfish Diversity and Food Web Structure." Ocean \& Coastal Management (102): 258-268. http://dx.doi.org/10.1016/j.ocecoaman.2014.10.004

Sulistiyono, Singgih Tri. 2017. "Tracking the Role of Education in Preserving National Identity: Maritime Aspects in the History Subject at Senior High School in Indonesia." Journal of Maritime Studies and National Integration 1 (1): 55-65. https://doi.org/10.14710/jmsni.v1i1.1373

Spiekermann, Raphael., Stefan Kienberger, , John Norton, Fernando Briones, and Juergen Weichselgartner. 2015. "The Disaster-Knowledge Matrix - Reframing and Evaluating The Knowledge Challenges in Disaster Risk Reduction.” International Journal of Disaster Risk Reduction 13: 96-108. http://dx.doi.org/10.1016/j.ijdrr.2015.05.002

Windarsari, Ranulin. 2017. "Character Education Through History Learning on Formal Education." Proceesing of education language international conference (ELIC), Universitas Islam Sultan Agung. jurnal.unissula.ac.id, index.php , ELIC, article, download

Windarsari, Ranulin., Djono and Sunardi. 2017. "Local Knowledge in Non-formal Education: A Case Study in Historical Learning at SKB Sukoharjo." Advances in Social Science, Education and Humanities Research (ASSEHR) 158 International Conference on Teacher Training and Education (ICTTE). https://download.atlantis-press.com > article

Wasino. 2017. "Maritime Content in Indonesian History Education: The Development and Alternative Solution.” Journal of Maritime Studies and National Integration, 1 (2): $112-$ 117. https://doi.org/10.14710/jmsni.v1i2.1997 
Yochum, Noëlle., Richard M. Starr \& Dean E Wendt. 2011. "Utilizing Fishermen Knowledge and Expertise: Keys to Success for Collaborative Fisheries Research.” Fisheries 36 (12): 593-605. DOI: $10.1080 / 03632415.2011 .633467$ 